\title{
Pengaruh Model Pembelajaran Sinektik Terhadap Hasil Belajar Fisika Pada Siswa Kelas X SMA Negeri 4 Palu
}

\author{
Silva Agustina, Marungkil Pasaribu dan Sahrul Saehana \\ e-mail: Silva.agustina77@yahoo.co.id \\ Program Studi Pendidikan Fisika FKIP Universitas Tadulako \\ Jl. Soekarno Hatta Km. 9 Kampus Bumi Tadulako Tondo Palu - Sulawesi Tengah
}

\begin{abstract}
Abstrak - Penelitian ini bertujuan untuk mengetahui ada tidaknya pengaruh model pembelajaran sinektik terhadap hasil belajar fisika pada siswa kelas X di SMA Negeri 4 Palu. Jenis penelitian yang digunakan adalah eksperimen kuasi dengan desain "The Non Equivalen Pretest-Posttest Design". Sampel dipilih dengan menggunakan teknik purposive sampling. Sampel penelitian kelas X MIA 1 sebagai kelas eksperimen dan kelas $\mathrm{X}$ MIA 2 sebagai kelas kontrol. Instrumen yang digunakan berupa tes hasil belajar fisika dalam bentuk pilihan ganda. Berdasarkan hasil pengolahan data, untuk kelas eksperimen diperoleh rerata skor pretest hasil belajar fisika siswa kelas eksperimen adalah 8,96 dengan standar deviasi 2,41 dan untuk posttest adalah 15,61 dengan standar deviasi 2,23. Untuk kelas kontrol diperoleh rerata skor pretest 7,04 dengan standar deviasi 2,22 sedangkan untuk posttest 12,07 dengan standar deviasi 2,04. Analisis data tes dilakukan dengan teknik statistik uji-t dua pihak untuk menguji perbedaan rerata skor hasil belajar fisika siswa dengan jumlah sampel sebanyak $a=0,05$. Hasil pengujian hipotesis diperoleh nilai hasil $t_{\text {hitung }}=6,21$ dan $t_{\text {tabel }}=1,67$. Ini berarti bahwa nilai $t_{\text {hitung }}$ berada diluar daerah penerima $\mathrm{Ho}$. Hal ini menyatakan terdapat perbedaan pengaruh model pembelajaran sinektik terhadap hasil belajar,sehingga dapat disimpulkan bahwa model pembelajaran sinektik ini berpengaruh terhadap hasil belajar karena dapat mendorong dan menginspirasi siswa berfikir kritis, analisis, dan tepat dalam mengidentifikasi, memahami, memecahkan masalah, dan mengaplikasikan materi pembelajaran sehingga siswa lebih mudah mengingat materi pembelajaran yang telah diberikan oleh guru.
\end{abstract}

Kata Kunci: Model Pembelajaran Sinektik, Hasil Belajar Fisika

\section{PENDAHULUAN}

Pendidikan yang efektif adalah suatu pendidikan yang memungkinkan peserta didik untuk dapat belajar dengan mudah, menyenangkan dan dapat tercapai tujuan sesuai dengan yang diharapkan. Kondisi dalam dunia pendidikan saat ini masih terdapat kekurangan yaitu pembelajaran yang masih berpusat pada guru yang menyebabkan siswa pasif serta siswa tidak dapat mengeluarkan gagasannya sehingga hasil belajar rendah.

Pembelajaran fisika yang berlangsung saat ini masih cenderung menggunakan pembelajaran konvensional.Pembelajaran konvensional pada umumnya memiliki kekhasan tertentu, misalnya lebih mengutamakan hafalan dari pada pemahaman, menekankan kepada keterampilan berhitung, mengutamakan hasil daripada proses, dan pengajaran berpusat pada guru. Guru yang memakai metode ini cenderung memiliki siswa yang kurang aktif dalam proses pembelajara, dan hanya siswa yang bertipe auditif (mendengarkan) yang benar-benar menerimanya, sehingga siswa cenderung mudah jenuh, kurangnya perkembangan sikap kemandirian belajar pada siswa, siswa akan menganggap dirinya bergantung pada guru. Setyiawan (2011). ${ }^{[1]}$
Beberapa faktor yang mempengaruhi rendahnya hasil belajar siswa yaitu semangat belajar siswa yang kurang, sarana belajar yang belum memadai, penggunaan metode mengajar yang tidak efektif dan variatif.

Pada hakekat sebenarnya dari pembelajaran fisika yaitu pembelajaran yang diperoleh melalui eksperimen dan bersifat kuantitatif. Untuk mengatasi permasalahan tersebut di atas, dibutuhkan suatu inovasi dan kreatifitas yang tinggi baik dari pendidik maupun peserta didik dalam menghadapi pelajaran, khususnya pada mata pelajaran fisika yang menekankan teori. Salah satu alternatif model pembelajaran yang dapat digunakan adalah model pembelajaran sinektik. Dimana model pembelajaran sinektik itu sendiri mempunyai pengertian model pembelajaran yang memandang suatu masalah dengan cara membandingkannya dengan masalah lain yang memiliki persamaan yang sama.

Konsep pembelajaran ini mempunyai kriteria mendorong dan menginspirasi siswa berfikir kritis, analisis, dan tepat dalam mengidentifikasi, memahami, memecahkan masalah, dan mengaplikasikan materi pembelajaran.

Khairani, dkk (2013) berhasil mengungkapkan fakta bahwa siswa kelas eksperimen dengan kelas kontrol pada ranah 
kognitif (berfikir kreatif), afektif (sikap kreatif), dan psikomotor (keterampilan kreatif) secara signifikan pada taraf nyata 0,05 perbedaan disebabkan oleh penerapan Synectics Lesson. ${ }^{[2]}$

Aztry (2012) berhasil mengungkapkan bahwa model sinektik efektif pada pembelajaran yang dilakukan pada kelas kemandirian tinggi maupun pada kelas kemandirian rendah. ${ }^{[3]}$

Berdasarkan penjelasan diatas maka penulis mengaitkan masalah yang dialami siswa karena rendahnya hasil belajar, ketertarikan, serta daya tanggap siswa yang berbeda-beda, sehingga penulis mencoba untuk membuat siswa paham bukan hanya sebagai konsep saja melainkan mempraktekannya, sehingga siswa yang memiliki kemampuan daya tangkap kurang apabila saat guru hanya menggunakan pembelajaran konvensional saja terhadap pelajaran fisika, bisa memahami pelajaran ini dan dapat meningkatkan hasil belajar siswa.

Berdasarkan uraian pada latar belakang di atas, maka dapat dirumuskan permasalahan sebagai berikut: "Apakah terdapat pengaruh model pembelajaran sinektik terhadap hasil belajar fisika pada siswa kelas $X$ di SMA Negeri 4 Palu".

\section{METODE PENELITIAN}

Adapun desain penelitian menggunakan metode kuasi eksperimen, dimana desain penelitian yang digunakan adalah "The Non Equivalen Pretest-Posttest Design" atau Rancangan Prates-Posttest yang Ekuivalen, yaitu menggunakan kelas-kelas yang sudah ada sebagai kelompoknya, dengan memilih kelaskelas yang diperkirakan sama keadaan/kondisinya. Bentuk desainnya disajikan seperti tabel 3.1

Tabel 1. Rancangan Penelitian

\begin{tabular}{|l|c|c|c|}
\hline \multicolumn{1}{|c|}{ Kelompok } & $\begin{array}{c}\text { Tes } \\
\text { Awal }\end{array}$ & Perlakuan & $\begin{array}{c}\text { Tes } \\
\text { Akhir }\end{array}$ \\
\hline A(Eksperimen) & $\mathrm{O}_{1}$ & $\mathrm{X}_{1}$ & $\mathrm{O}_{2}$ \\
B (Kontrol) & $\mathrm{O}_{1}$ & $\mathrm{X}_{2}$ & $\mathrm{O}_{2}$ \\
\hline
\end{tabular}

Keterangan :

A : Kelompok eksperimen

B : Kelompok kontrol

$\mathrm{O}_{1}$ : Tes Awal

$\mathrm{O}_{2}$ : Tes Akhir

$\mathrm{X}$ :erlakuan dengan model pembelajaran sinektik ${ }^{[4]}$

Penelitian dilakukan di SMA Negeri 4 Palu, pada tahun ajaran baru 2014-
2015.Semester Dua (Genap) bulan Januari 2015.

Populasi dalam penelitian ini yaitu seluruh kelas $X$ SMA Negeri 4 Palu yang terdaftar dalam tahun ajaran 2014-2015. Pemilihan sampel dalam penelitian ini dilakukan di SMA Negeri 4 Palu, sehingga Sampel dari penelitian ini adalah sebagian dari siswa kelas $X$ SMA Negeri 4 Palu yaitu kelas $X$ MIA 1 sebagai kelas eksperimen dan kelas $X$ MIA 2 sebagai kelas kontrol. Penarikan sampel pada penelitian ini ditentukan dengan menggunakan teknik purposive sampling atau "penentuan sampel dengan pertimbangan tertentu", dimana berdasarkan hasil observasi yang dilakukan diketahui bahwa kedua kelas ini memiliki jumlah siswa yang samayaitu 28 siswa kelas X MIA 1 dan 28 seswa kelas X MIA 2 kedua kelas ini memiliki kemampuan belajar yang kurang lebih sama terutama pada pelajaran Fisika.

Berdasarkan hasil validitas ahli dan uji coba tes, dari 30 soal yang diuji cobakan pada XI SMA Negeri 6 Palu, tidak semua soal dianggap memenuhi syarat (Valid). 10 soal yang tidak valid, sehingga soal yang digunakan sebagai tes hasil belajar fisika totalnya berjumlah 20 soal.

Teknik analisis data dalam penelitian ini terlebih dahulu dilakukan uji normalitas, Uji Homogenitas, Sedangkan pengujian hipotesis yang digunakan adalah uji t (uji dua pihak). Jenis uji statistika ini bertujuan untuk membandingkan rata-rata dua grup yang saling berpasangan.Sudjana (2005). ${ }^{[5]}$

\section{HASIL DAN PEMBAHASAN}

1. Hasil Penelitian

\section{Uji Normalitas Hasil Belajar Pretestdan Posttest}

Tabel 2 Hasil Uji Normalitas Tes Awal dan tes akhir Kelas Eksperimen dan Kelas Kontrol

\begin{tabular}{|c|c|c|c|c|}
\hline \multirow{2}{*}{ Uraian } & \multicolumn{2}{|c|}{ Tes Awal } & \multicolumn{2}{c|}{ Tes Akhir } \\
\cline { 2 - 5 } & Eksperimen & Kontrol & Eksperimen & kontrol \\
\hline Sampel & 28 & 28 & 28 & 28 \\
\hline$X^{2}$ hitung & 0,58 & 0,46 & 0,51 & 0,91 \\
\hline$X^{2}$ tabel & \multicolumn{2}{|c|}{5,99} & \multicolumn{2}{c|}{5,99} \\
\hline $\begin{array}{c}\text { Keteranga } \\
n\end{array}$ & \multicolumn{2}{|c|}{ Normal } & \multicolumn{2}{c|}{ Normal } \\
\hline
\end{tabular}


Uji Homogenitas Hasil Belajar Pretest dan Posttest

Tabel 3 : Uji Homogenitas Tes Awal dan Tes Akhir

\begin{tabular}{|l|c|c|l|}
\hline Uraian & Tes Awal & Tes Akhir & Keterangan \\
\hline$F_{\text {hitung }}$ & 0,96 & 0,27 & \multirow{2}{*}{ Homogen } \\
\hline$F_{\text {tabel }}$ & 1,89 & 1,89 & \\
\hline
\end{tabular}

\section{Uji Rerata Kelas Eksperimen dan Kelas Kontrol}

Tabel 4 : Uji Rerata Kelas Eksperimen dan Kelas Kontrol

\begin{tabular}{|c|l|c|c|c|c|}
\hline $\begin{array}{l}\mathbf{N} \\
\mathbf{0}\end{array}$ & Kelas & $\overline{\mathbf{X}}$ & $\mathbf{t}_{\text {hitung }}$ & $\begin{array}{l}\mathbf{t}_{\text {tabel }} \\
(\boldsymbol{\alpha}=\mathbf{0 5})\end{array}$ & Keputusan \\
\hline 1 & Eksperimen & 8,96 & \multirow{2}{*}{1,20} & 2,00 & $\mathbf{H}_{\mathbf{0}}$ diterima \\
\hline 2 & Kontrol & 8,25 & & & \\
\hline
\end{tabular}

\section{Uji Hipotesis Hasil Belajar Fisika}

Tabel 5 Uji Hipotesis Hasil Belajar

\begin{tabular}{|l|c|c|c|l|}
\hline \multicolumn{1}{|c|}{ Kelas } & $\overline{\mathrm{X}}$ & $\mathbf{t}_{\text {hitung }}$ & $\begin{array}{c}\mathbf{t}_{\text {tabel }}(\boldsymbol{\alpha} \\
\mathbf{0} \\
\mathbf{0 , 0 5}\end{array}$ & Keputusan \\
\hline Eksperimen & 15,61 & \multirow{2}{*}{4,54} & 2,00 & $\mathbf{H}_{\mathbf{1}}$ diterima \\
\hline Kontrol & 12,10 &, 54 \\
\hline
\end{tabular}

Berdasarkan Tabel $4.6 t_{\text {itung }}>t_{\text {tabel }}$ atau 4,54> 2,00 . Hal ini berarti, nilai $t_{\text {hitung }}$ berada diluar daerah penerimaan $\mathrm{H}_{0}$. Dengan demikian $\mathrm{H}_{0}$ ditolak dan $\mathrm{H}_{1}$ diterima. Hal ini menunjukkan bahwa terdapat perbedaan hasil perubahan konsep antara kelas eksperimen ( X MIA 1) dengan kelas kontrol ( $X$ MIA 2).Artinya, setelah diberi perlakuan yang berbeda,terdapat perbedaan hasil perubahan konsep siswa antara kelas eksperimen dengan kelas kontrol.

\section{A. Deskripsi Hasil Belajar Pretest}

Berdasarkan hasil pemberian tes awal diketahui skor minimum yang diperoleh siswa kelas eksperimen adalah 4 dan skor maksimumnya adalah 12 . Skor rata-rata kelas eksperiment sebesar 8,96 dengan standart deviasi sebesar 2,41. Sedangkan untuk kelas control skor minimum yang diperoleh siswa sebesar 2 dan skor maksimumnya sebesar 11. Skor rata-ratanya 7,04 dengan standar deviasinya 2,22. Berikut data hasil penelitian disajikan dalam bentuk table sebagai berikut :

Tabel 6. Deskripsi skor tes hasil belajar siswa kelas eksperiment dan kelas kontrol

\begin{tabular}{|l|c|c|}
\hline Deskripsi & $\begin{array}{l}\text { Kelas VII D } \\
\text { (Eksperimen) }\end{array}$ & $\begin{array}{l}\text { Kelas VII F } \\
\text { (Kontrol) }\end{array}$ \\
\hline Jumlah Siswa & 28 & 28 \\
\hline Skor Minimum & 4 & 2 \\
\hline Skor Maksimum & 12 & 11 \\
\hline Skor Total & 251 & 197 \\
\hline Skor Rata-rata & 8,96 & 7,04 \\
\hline Standar Deviasi & 2,41 & 2,22 \\
\hline
\end{tabular}

\section{$\square$ Pretest Eksperimen $\quad$ Pretest Kontrol}

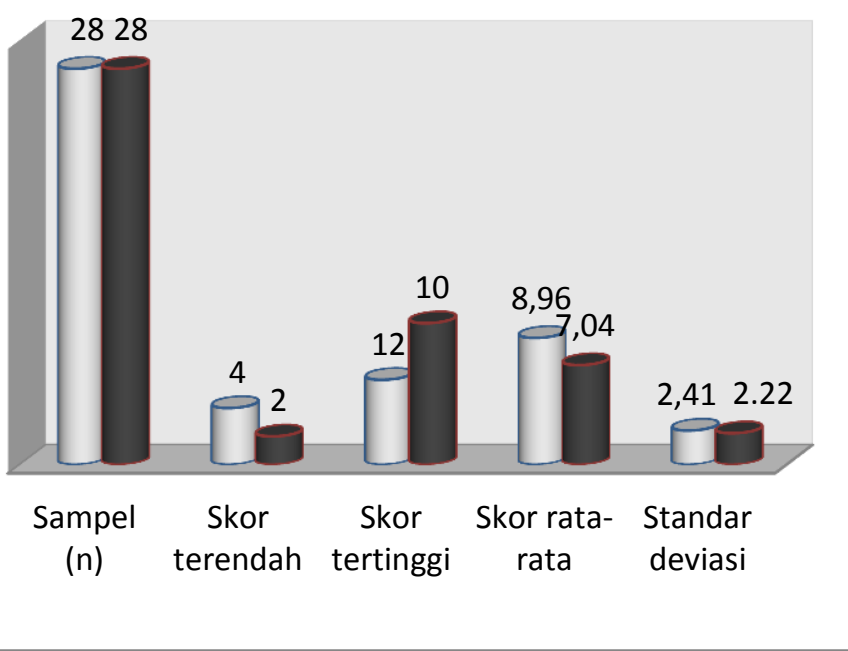

Gambar 1. Grafik Skor Tes Hasil Belajar Siswa (Pretest)

\section{B. Deskripsi Hasil Belajar Posttest}

Hasil yang diperoleh dari tes akhir yaitu skor rata-rata kelas eksperiment sebesar 15,61 dengan standart deviasi sebesar 2,23. Sedangkan untuk kels kontrol skor minimum yang diperoleh siswa adalah 7 dan skor maksimumnya adaalah 16 . Skor rata-rata kelas kontrol sebesar 12,07 dengan standart deviasi 2,04 . Adapun data hasil penelitian diatas, disajikan dalam table 5 , data tersebut dapat dilihat pada grafik 2 berikut ini :

Tabel 7. Deskripsi skor tes hasil belajar siswa kelas ekesperimen dan kelas kontrol (Posttest).

\begin{tabular}{|l|c|c|}
\hline Deskripsi & $\begin{array}{l}\text { Kelas VII D } \\
\text { (Eksperimen) }\end{array}$ & $\begin{array}{c}\text { Kelas VII F } \\
\text { (Kontrol) }\end{array}$ \\
\hline Jumlah Siswa & 28 & 28 \\
\hline Skor Minimum & 11 & 7 \\
\hline Skor Maksimum & 19 & 16 \\
\hline Skor Total & 437 & 338 \\
\hline Skor Rata-rata & 15,61 & 12,07 \\
\hline Standar Deviasi & 2,23 & 2,04 \\
\hline
\end{tabular}


Posttest Eksperimen $\quad \square$ Posttest Kontrol

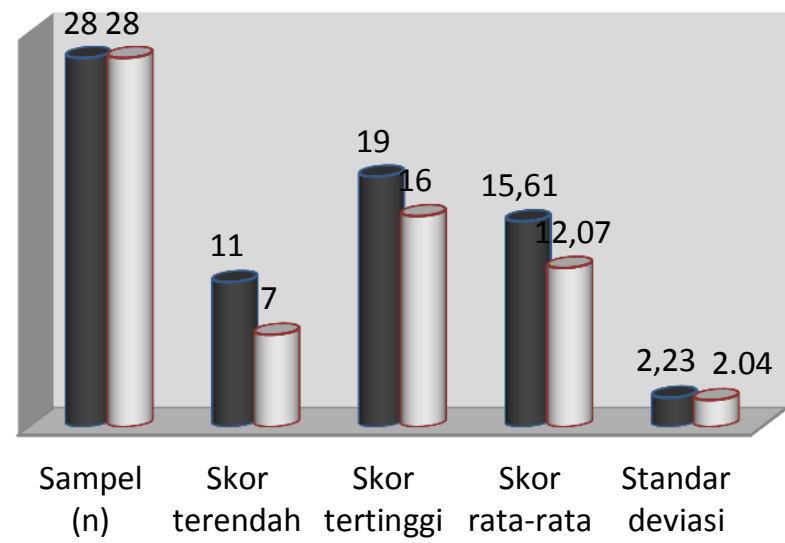

Gambar 2. Grafik Skor Tes Hasil Belajar Siswa (Posttest)

\section{Pembahasan}

Penelitian ini dilakukan untuk menguji signifikansi pengaruh model pembelajaran sinektik terhadap hasil belajar fisika siswa pada materi Suhu dan Kalor kelas X di SMA Negeri 4 Palu. Pada penelitian ini kegiatan pembelajaran dilakukan sebanyak 6 kali pertemuan, 2 kali pertemuan untuk pemberian soal pretest dan posttest dan 3 kali pertemuan tatap muka masing-masing pada kelas eksperiment maupun kelas control.

Tes awal (pretest) yang diberikan bertujuan untuk mengetahui kemampuan awal siswa dikedua kelas, selanjutnya digunakan untuk menentukan kelompok dan juga sebagai data analisis penelitian.Sedangkan tes akhir (posttest) diberikan untuk mengetahui kemampuan akhir siswa di kedua kelas dan sebagai data analisis penelitian yang selanjutnya digunakan sebagai pembanding untuk melihat apakah terdapat perbedaan model sinektik terhadap hasil belajar fisika siswa antara kedua kelas tersebut pada materi Suhu dan Kalor.

Berdasarkan hasil analisis kuantitatif tes awal hasil belajar siswa menunjukkan skor rata-rata kelas eksperimen sebesar 8,96 dengan standar deviasi 2,41 dan skor rata-rata untuk kelas kontrol sebesar 7,04 dengan standar deviasi 2,22. Hasil ini menunjukkan bahwa terdapat perbedaan skor antara kelas eksperimen dan kelas kontrol, dimana kelas eksperimen lebih tinggi dibandingkan kelas kontrol.Analisis tes akhir menunjukkan hasil yang berbeda, terlihat bahwa hasil analisis kuantitatif hasil belajar menunjukkan skor ratarata siswa kelas eksperimen sebesar 15,61 dengan standar deviasi 2,23 dan skor rata-rata siswa kelas kontrol sebesar 12,07 dengan standar deviasi 2,04.

Berdasarkan analisis kuantitatif data posttest diketahui,nilai rata-rata kelas eksperimen lebih besar dibandingkan dengan nilai rata-rata kelas kontrol Perbedaan antara rerata skor posttest kelas eksperimen dan kelas kontrol menunjukkan adanya pengaruh model pembelajaranyang diterapkan pada kedua kelas tersebut. Pengaruh yang signifikan terjadi pada kelas eksperimen.Dimana kelas eksperimen menggunakan model sinektik terhadap hasil belajar siswa sedangkan kelas kontrol menggunakan model konvensional. Setelah dilakukan uji normalitas dan homogenitas varians, selanjutnya dilakukan uji hipotesis dengan menggunakan uji-t dua pihak tes akhir.Dari perhitungan hipotesis diperoleh nilai $t_{\text {hitung }}=4,54$ dan nilai $t_{\text {tabel }}=2,00$ Dengan menggunakan kriteria penerimaan $\mathrm{H}_{0}$ dimana $\mathrm{t}_{(1-0,5 \mathrm{a})}<\mathrm{t}<\mathrm{t}_{(1-0,5 \mathrm{a})}$, diketahui hipotesis $\mathrm{H}_{0}$ tidak terpenuhi atau ditolak dan hipotesis satu $\left(\mathrm{H}_{1}\right)$ diterima. Artinya terdapat pengaruh model pembelajaran sinektik secara signifikan terhadap hasil belajar siswa pada konsep suhu dan perubahannya di SMA Negeri 4 Palu.

Pada skor tes akhir pada kelas eksperimen dan kelas kontrol cukup berbeda, rata-rata skor untuk kelas eksperimen sebesar 15,61 dengan standar deviasi 2,23 dan skor rata-rata untuk kelas kontrol sebesar 12,07 dengan standar deviasi 2,04. Secara kuantitas hasil ini menunjukkan perbedaan yang signifikan, skor tersebut menunjukkan kelas eksperimen memperoleh skor rata-rata yang tinggi dibanding dengan kelas kontrol.

Terjadinya perbedaan hasil tes pemahaman konsep terutama pada kelas eksperimen, dimungkinkan karena pada proses pembelajaran menggunakan model sinektik menjadikan siswa lebih aktif dalam proses pembelajarandan terlibat langsung dalam proses pembelajaran dimana informasi dan pengetahuan mereka temukan secara mandiri dalam kelompok, saling berinteraksi bukan hanya dengan guru tetapi juga dengan teman mereka, dengan model pembelajaran yang digunakan membuat siswa menjadi lebih kreatif dalam menyelesaikan masalah dan menerapkan ilmu fisika dalam kehidupan sehari-hari.

Pada materi suhu dan perubahannya, siswa banyak menemukan hal-hal yang berkaitan dengan materi yang diajarkan, contohnya mengapa pada siang hari kita merasakan panas dan pada malam hari kita merasakan dingin, siswa dapat membedakan perbedaan suhu yang terjadi pada saat siang hari dan malam hari, disini siswa dapat 
membedakan suhu yang panas dengan suhu yang dingin. Dari hasil tersebut siswa bias menyadari akan banyak hal dan makna dari belajar fisika.

Kondisi pembelajaran didalam kelas pada saat menggunakan model pembelajaran sinektik, siswa lebih aktif dalam memandang suatu masalah dengan cara membandingkannya dengan masalah lain yang dapat disamakan maksudnya,siswa juga dapat mengembangkan kreativitas sehingga timbulnya ide-ide kreatif untuk menggambarkan suatu masalah yang telah diberikan.

Khairani, dkk (2013) dalam penelitiannya menyatakan bahwa model pembelajaran sinektik dapat meningkatkan hasil belajar siswa, selain itu pembelajaran sinektik juga dapat melatih keterampilan berpikir kreatif siswa. Berdasarkan respon siswa terhadap pembelajaran, siswa lebih mudah untuk menerima, mengerti, dan memahami materi. ${ }^{[2]}$

Dari hasil penelitian ini dapat disimpulkan bahwa Uji model menunjukkan hasil belajar siswa yang mengikuti pembelajaran sinektik lebih baik daripada siswa yang mengikuti pembelajaran menggunakan model konvensional tanpa melakukan eksperimen.

\section{KESIMPULAN}

Berdasarkan penelitian dan analisis data dapat disimpulkan, bahwa model pembelajaran yang digunakan ini memberikan dampak positif terhadap hasil belajar siswa. Hal ini dapat dilihat berdasarkan hasil post-test hasil belajar siswa skor rata-rata kelas kontrol sebesar 12,07 dengan standar deviasinya adalah 2,04 dan skor rata-rata kelas eksperimen sebesar 15,61 dengan standar deviasinya adalah 2,23 dari skor maksimum 19. Untuk hasil Pengujian hipotesis yang menggunakan uji-t dua pihak pada post-test dengan menggunakan nilai rata-rata skor diperoleh nilai $t_{\text {hitung }}=4,54>t_{\text {tabel }} 2,00$, dengan taraf nyata 0,05 dan $\mathrm{dk}=(28+28)-2=54$. Hasil kriteria ini berada di luar daerah penerimaan $\mathrm{H}_{0}$ maka terdapat perbedaan hasil belajar Fisika antara yang menggunakan model pembelajaran sinektik dengan model pembelajaran konvensional.Dengan demikian $\mathrm{H}_{0}$ ditolak dan $\mathrm{H}_{1}$ diterima dan dapat disimpulkan bahwa ada pengaruh model pembelajaran sinektik terhadap hasil belajar Fisika pada siswa kelas X SMA Negeri 4 Palu.

\section{DAFTAR PUSTAKA}

[1] Setyawan, (2011). penilaian hasil belajar berdasarkan aspek kognitif, afektif, dan psikomotor.Kencana Prenada Media Group: Jakarta.
[2] Rizki Khairani, Yurnetti, Hamdi, (2013).Pengaruhpenerapansynectics lesson dalam pembelajaran ipa fisika untuk meningkatkan kompetensi siswa kelas viii di smpn 1 solok. (Skripsi Vol. 2. Oktober 2013). Padang: Universitas Negeri Padang.

[3] Aisiyah Aztry, (2012). Keefektifan Model Sinektik Dan Penemuan Konsep Pada Pembelajaran Menulis Puisi Berdasarkan Tingkat Kemandirian Siswa Kelas VII Smp. (Jurnal Vol. 1. Februari 2012).Semarang : Universitas Negeri Semarang.

[4] Sugiyono, (2008). Metode Penelitian Pendidikan.Bandung: Alfabeta.

[5] Sudjana, (2005). Metode Statistika. Bandung: Tarsito. 